\title{
Determinants of Transfer Pricing Decisions in Mining Companies Listed on the Indonesian Stock Exchange
}

\author{
Ade Maya Saraswati* \\ Universitas Muhammadiyah Prof.DR HAMKA, Indonesia, ademayahasan@gmail.com \\ *corresponding author
}

\begin{abstract}
This research aims to analyse the effect of tax and tunnelling incentive to transfer pricing with good corporate governance as a moderating variable. This research focuses on all mining companies listed on the Indonesian Stock Exchange in the period from 2014-2018 by using the purposive sampling technique to determine the sample. There are 90 data observations used as the sample and analysed by using logistic regression and moderation regression analysis, with the help of the SPSS 20 program. The research result shows that tax has a positive effect on the decision of transfer pricing; tunnelling incentive does not have an effect on the decision of transfer pricing. Good corporate governance moderates the effect of tax to transfer pricing, meanwhile good corporate governance does not moderate the effect of tunnelling incentive to the decision of transfer pricing.
\end{abstract}

Keywords: Good corporate governance; Tax; Transfer pricing; Tunnelling incentive

\section{Determinan Keputusan Transfer Pricing pada Perusahaan Pertambangan yang Terdaftar di Bursa Efek Indonesia}

\begin{abstract}
Abstrak
Penelitian ini bertujuan untuk menganalisis pengaruh pajak dan tunnelling incentive terhadap transfer pricing dengan good corporate governance sebagai variabel pemoderasi. Populasi dari penelitian ini adalah seluruh perusahaan pertambangan yang terdaftar di Bursa Efek Indonesia tahun 2014-2018 dengan penentuan sampel menggunakan teknik purposive sampling. Sampel dalam penelitian berjumlah 90 observasi data yang kemudian dianalisis menggunakan regresi logistik dan analisis regresi moderasi dengan bantuan program SPSS 20. Hasil penelitian menunjukkan bahwa pajak berpengaruh positif terhadap keputusan transfer pricing, tunnelling incentive tidak berpengaruh terhadap keputusan transfer pricing, good corporate governance memoderasi pengaruh pajak terhadap transfer pricing, sedangkan good corporate governance tidak memoderasi pengaruh tunnelling incentive terhadap keputusan transfer pricing.
\end{abstract}

Kata kunci: Good corporate governance; Pajak, Transfer pricing, Tunnelling incentive

\section{INTRODUCTION}

In the business sector and international economy, transfer pricing is considered an important and critical issue. Transfer pricing is defined as a predetermined price or reward in relation to the process of moving goods, services and technology to affiliated parties (Hidayat 2018). However, based on the fact in the field, transactions made with affiliated parties can cause an unreasonable price, expenses or other rewards provided in the form of a business transaction. Besides that, transfer pricing negatively impacted developing countries i.e. revenue decreased from the tax sector. In addition, tax gives a contribution of at least $80 \%$ from total revenue and becomes the main source of a country's income, especially in developing countries (Jafri and Mustikasari 2018). 
The transaction referred can cause a transfer of revenue, which is the basis to determine the value of tax and can also be used to manipulate the amount of tax to be paid by taxpayers (Hartati, Desmiyawati 2015). Most of the investment in the mining sector in source countries, such as Indonesia, is dominated by foreign capital. This fact causes the mineral and coal sector to be export-oriented to investors' home countries. This is due to the fact that most of the mining products are raw materials for the manufacturing industry, which require further processing. When determining the selling price of the mined products, especially for sales transactions to affiliates abroad, determining the fairness of the selling price of the product is basically very difficult to identify. Regarding the overall supply chain scheme in a multinational group, various transactions such as the provision of management services, marketing or royalty fees for the use of technology, skills, trademarks or reputation also poses challenges in overcoming tax avoidance.

Indonesian Mining Association released data showing that Indonesia is the sixth place among countries that have abundant mining resources. This fact made strategically positioned the mining sector to drive the wheels of economy in Indonesia. However, from so many business sectors, one business sector that often avoids tax payments is the mining sector that uses a transfer pricing method (Sari and Puryandani 2019). This issue is confirmed by the Corruption Eradication Commission (KPK), which stated that the mining sector had caused the country a loss of $\mathrm{Rp} \$ 15.9$ trillion per year because of avoiding paying taxes for forest areas (Novriansa 2019).

The tax aspect is also a factor to be considered by the company in manipulating tax payments through the scheme of transfer pricing. Transfer pricing aims to manipulate total revenues received by the company to generate lower tax payment and dividend that needs to be distributed (Rosa et al, 2017). Consistent with it, Hartati et al. (2015) stated that the strategy of transfer pricing is done by moving revenues and expenses of an entity with affiliated parties overseas that apply different tax rates.

Several studies on transfer pricing behaviour that are influenced by tax motivation have been conducted before, including Lo, Wong and Firth (2010), finding that taxes have an effect on transfer pricing behaviour. The results of this study are supported by the research of (Marfuah, Nurlaela and Wijayanti 2019), which states that multinational companies make transactions with companies that have special relationships in other countries with the aim of reducing the amount of taxes paid by a company. However, the results of tests conducted by Yuniasih (2017) and Noviastika, Mayowan and Karjo (2016) show that taxes have no effect on transfer pricing, because companies can use other means besides transfer pricing to minimise the tax burden paid. In order to measure how well a company manages its taxes, one needs to look at the effective rate. Yulianti and Rachmawati (2019) argues that in general, multinational companies that run their business in the mining sector face two main challenges, namely reducing taxes by changing the supply chain scheme in the country of origin and determining their selling price.

Another thing that encourages companies to do transfer pricing is shareholding. In general, Indonesia has a more dominant shareholding structure concentrated on the 
company owner in small amounts or less. That results in agency conflict between majority shareholders and minority shareholders. A concentrated shareholding system that is implemented by Indonesia makes shareholders as the majority party or leader and minority party (Noviastika, Mayowan, and Karjo 2016).

A manager is selected by the majority shareholder; therefore, the practice of tunnelling incentive can be done more freely and does not distribute dividend nor sell company assets to a majority shareholder or company run by a manager by providing lower selling price as the requirement (Syam 2017). Based on the research result conducted by Ulum (2017), he found that tunnelling incentive had a positive impact on the decision taken by the company in order to be able to do transfer pricing. Consistent with that research, Kurniawan (2018) also added that the transactions made with affiliated parties can prevent opportunity goals from controlling shareholders in order to start tunnelling incentive.

Research conducted by Saraswati and Sujana (2017) shows the effect of tunnelling incentives on transfer pricing behaviour, where companies with ownership are only controlled by several parties. Those who control the company tend to act only to benefit themselves. Research conducted by Ohnuma and Kato (2015) and Muhammadi et al. (2016) revealed empirical evidence that intangible assets have no effect because the number of intangible asset transactions does not reflect the opportunistic actions of company management engaging in transfer pricing behaviour. In addition, the valuation of intangible assets is not easy, because determining the value under the same conditions must be done with a third or independent party, but on average, transactions of intangible assets are carried out with one group or class party.

Good corporate governance always pushes a company make decisions carefully, especially when it comes to activities that can violate regulations. Therefore, corporate governance is crucial in running the practice of transfer pricing. Besides that, the application of good corporate governance causes a company to look at other options aside from profit (Gandasari \& Herawaty, 2015). By applying good corporate governance, the company can be run healthier, comply with all forms of regulation and care for the environment based on high socio-cultural values (Putri 2019).

Referring to the explanation described in the background above, this research conducts a test about the effect of tax and tunnelling incentive to transfer pricing; this is moderated by good corporate governance. The problem formulations in this research are: (1) Is there an impact of tax to transfer pricing decision in mining companies listed on the Indonesian Stock Exchange?; (2) Is there an impact of tunnelling incentive to transfer pricing decision in mining companies listed on the Indonesian Stock Exchange?; (3) Does good corporate governance moderate the impact of tax to transfer pricing in mining companies listed on the Indonesian Stock Exchange?; (4) Does good corporate governance moderate the impact of tunnelling incentive to transfer pricing in mining companies listed on the Indonesian Stock Exchange? The purpose of this research is to know the effect of tax, tunnelling incentive to transfer pricing partially and also to know that good corporate governance moderates the effect between tax and tunnelling incentive to transfer pricing. 


\section{METHOD}

This research uses secondary data i.e. the annual financial reports of mining companies obtained from the official website www.idx.co.id. It uses logistic regression via the SPSS 20.0 program. The population of this research consists of 49 mining companies listed on the Indonesian Stock Exchange for the period from 2014-2018. The sample of this research uses the purposive sampling method, which involves a sample selection with certain requirement criteria. The criteria used in this research are: (i) mining companies listed on the Indonesian Stock Exchange in the period from 2014-2018; (ii) The sample company's consistent financial reports during the period from 2014-2018; (iii) The sample company does not suffer fiscal loss during the observation period, because if it suffers fiscal loss, then it won't have tax expense, so that it will become irrelevant in this research; (iv) The sample company does not have loss compensation for the previous five years; the amount of compensation accumulated does not exceed the fiscal year earnings' observation, because a company with loss compensation and accumulated compensation that exceeds fiscal profit during the year of observation will not have tax expense.

The first research model is used to test the effect of tax and tunnelling incentive to the practice of transfer pricing (without moderating variables) with logistic regression analysis developed from the model of Lo et al., (2010) by adding tax variables. And the equation formula is as follows:

$$
\mathrm{Y}=\alpha+\beta_{1} \mathrm{X}_{1}+\beta_{2} \mathrm{X}_{2}+\varepsilon
$$

The second research model is used for testing by adding moderating variables. The equation formula is as follows:

$$
\mathrm{Y}=\alpha+\beta_{1} \mathrm{X}_{1}+\beta_{2} \mathrm{X}_{2}+\beta_{3} \cdot \mathrm{X}_{1}^{*} \mathrm{Z}_{1}+\beta_{4} \cdot \mathrm{X}_{2}^{*} \mathrm{Z}_{1}+\varepsilon
$$

Which consists of:

$\mathrm{Y}=$ Transfer pricing that is measured by dummy

$\mathrm{X}_{1}=$ Tax rate that is measured by ETR ratio

$\mathrm{X}_{2}=$ Tunnelling incentive that is measured by dummy

$\mathrm{Z}_{1}$ = good corporate governance that is measured by dummy

$\alpha=$ Constant

$\beta_{1}=$ Tax regression coefficient to transfer pricing

$\beta_{2}=$ Tunneling incentive regression coefficient to transfer pricing

$\beta_{3}=$ Tax regression coefficient to transfer pricing

$\beta_{4}=$ Tax regression coefficient to transfer pricing, moderating good corporate governance

$\varepsilon=$ Error Standard

In order to find out transfer pricing, tunneling incentive, tax rate and good corporate governance, this research uses the following proxies: 


\section{FINDING AND DISCUSSION}

Table 1. Definition and Operational Research Variables

\begin{tabular}{|c|c|c|c|}
\hline No. & Variables & Definition & Measuring Result \\
\hline 1. & Transfer Pricing & $\begin{array}{l}\text { Transfer pricing is a company } \\
\text { policy to determine the transfer } \\
\text { price of a transaction, be it } \\
\text { goods, services, intangible } \\
\text { assets or financial transactions } \\
\text { carried out by the company } \\
\text { (Jafri and Mustikasari 2018) }\end{array}$ & $\begin{array}{c}\text { Score } 1=\text { related party sales } \\
\text { Score } 0=\text { non related party } \\
\text { sales }\end{array}$ \\
\hline 2. & $\begin{array}{l}\text { Tunnelling } \\
\text { Incentive }\end{array}$ & $\begin{array}{l}\text { Tunnelling incentives are } \\
\text { incentives obtained from the } \\
\text { transfer of company assets and } \\
\text { profits by the majority } \\
\text { shareholder but minority } \\
\text { shareholders share the burden } \\
\text { (Yuniasih 2017) }\end{array}$ & $\begin{array}{c}\text { Score } 1=\text { percentage of } \\
\text { share ownership }>=20 \% \text { as } \\
\text { majority shareholder } \\
\text { Score } 0=<20 \% \text { as minority } \\
\text { share ownership }\end{array}$ \\
\hline 3. & Tax rate & $\begin{array}{l}\text { The tax rate is the basis for the } \\
\text { imposition of tax on the tax } \\
\text { object, which is the } \\
\text { responsibility. The tax rate is } \\
\text { usually a percentage (\%). Tax } \\
\text { Imposition Basis is the value of } \\
\text { how much money is used to } \\
\text { calculate the tax owed } \\
\text { (Hidayat 2018) }\end{array}$ & ETR \\
\hline 4. & $\begin{array}{l}\text { Good corporate } \\
\text { governance }\end{array}$ & $\begin{array}{l}\text { GCG refers to a set of rules, } \\
\text { practices and company control } \\
\text { processes by involving the } \\
\text { balancing of the interests of } \\
\text { company stakeholders, such as } \\
\text { shareholders, management, } \\
\text { consumers, suppliers, } \\
\text { investors, government and } \\
\text { society (Sari and Puryandani } \\
\text { 2019) }\end{array}$ & $\begin{array}{c}\text { Score } 1=\text { KAP Big Ten } \\
\text { Score } 0=\text { Non KAP Big Ten }\end{array}$ \\
\hline
\end{tabular}

The total observation in the period of 2014-2018 shows 49 mining companies; some companies are excluded as the research sample based on the previously mentioned sample criteria due to delisting companies in the period of 2014-2018 (2 companies), no deferred 
tax expense (18 companies), IPO in the middle of observation year (5 companies), and does not present complete annual report (6 companies). From those criteria, there are 18 companies in the period of $2014-2018$ so that there are 90 observations in total. Based on descriptive statistical test result, it shows that there are 75 transfer pricing transactions, which means that it has been practiced by the majority of companies. Meanwhile the remaining 15 observations do not practice transfer pricing.

Tabel 2. Descriptive Statistics

\begin{tabular}{llllll}
\hline & \multicolumn{1}{c}{$\mathbf{N}$} & Minimum & Maximum & Mean & Std. Deviation \\
\hline Transfer Pricing & 90 & 0 & 1 & .83 & .375 \\
Pajak & 90 & -.241 & 1.654 & .36949 & .233888 \\
Tunnelling & 90 & 0 & 1 & .49 & .503 \\
Incentive & 90 & 0 & 1 & .78 & .418 \\
GCG & 90 & & & & \\
Valid N (listwise) & & & & & \\
\hline
\end{tabular}

The first research model is done using logistic regression analysis. The feasibility of the first research model uses Hosmer and Lemeshow's Goodness of Fit Test. The initial value of -2 Log Likelihood is 81.101. However, after the second independent variable is included, the final value of -2 Log Likelihood suffers impairment to 75.875. This impairment of -2 Log Likelihood shows that the regression model is better or, in other words, the model hypothesised is fit with the data.

Coefficient of determination is used to determine how much the variability of the dependent variable can be explained by the independent variable. Based on the results of tests conducted, the value of Nagelkerke $\mathrm{R}$ Square is 0.295 which means that the variability of the transfer pricing variable that can be explained by tax variable and tunnelling incentive variable is $29.5 \%$; the remaining $70.5 \%$ is explained by other variables outside the research model.

The calculation result of chi square in Hosmer and Lemeshow's Goodness of Fit Test according to Ghozali (2016:79) as a model compatibility test. Based on the calculation result of chi square, Hosmer and Lemeshow shows the value of 4.706 with significance probability of 0.788 far above the value of 0.05 . Therefore, it can be concluded that the model used is able to predict its observation value.

Based on the first model testing, the first hypothesis $\left(\mathrm{H}_{1}\right)$ is accepted; the research result showed that tax had a positive effect to transfer pricing with significance value of 0.004 and regression coefficient value of 8.933 . The higher the tax rate, the more it will trigger the company to the practice of transfer pricing. The second hypothesis $\left(\mathrm{H}_{2}\right)$ is rejected; the research result showed that tunnelling incentive had no significant effect to the practice of transfer pricing with significance value 0.064 and regression coefficient of 1.296. 
Jurnal Economia, 17(2), October 2021, 152-161

Table 3. Variable in the Equation

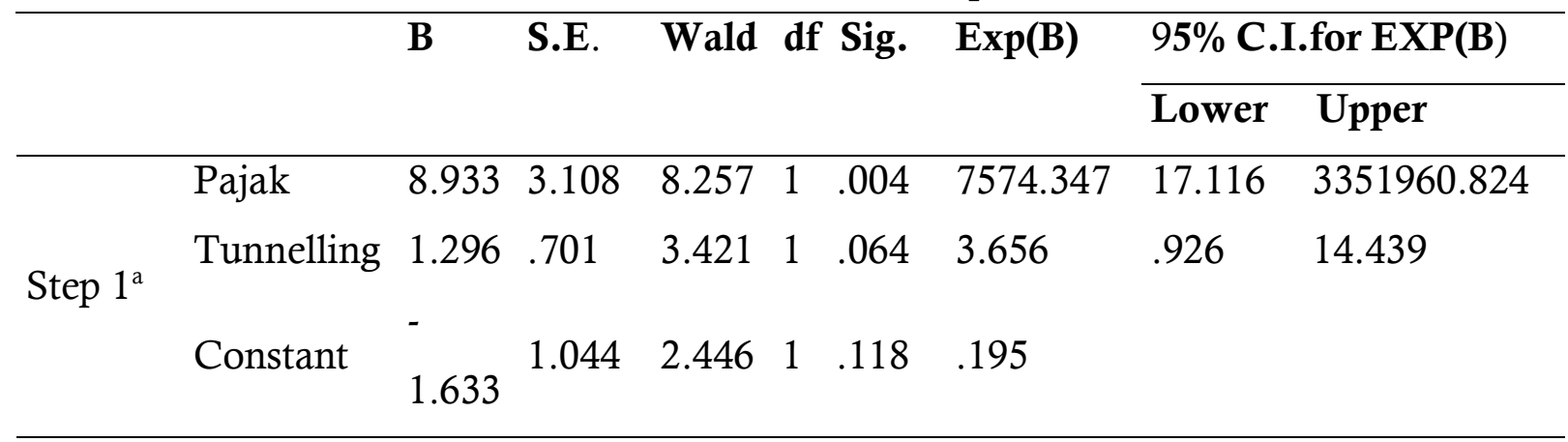

a. Variable(s) entered on step 1: Pajak, Tunneling.

This result is supported by the research of Hidayat (2018), who stated that business group minimised taxation obligations by transferring income through transactions with affiliated parties. Companies with high tax expense will reduce taxable income by doing business with affiliated parties with a lower tax rate through profitable requirements. A high tax rate triggered the company to practice transfer pricing. This result is consistent with the research conducted by Maraya et al (2016) and Hartati et al (2015). In their journal International Tax Prime, Arnold and McIntyre, two prominent professors in the field of tax law, said that transfer pricing is the price set by taxpayers when selling, buying and sharing resources with affiliates (Jafri and Mustikasari, 2018).

Yulianti and Rachmawati (2019) stated that tunnelling incentive was caused by the majority ownership of controlling shareholders and bad corporate governance; there was no effect of tunnelling incentive due to the good corporate governance. Jafri and Mustikasari (2018) also stated that tunnelling incentive had no effect to the practice of transfer pricing, because companies that practice Advance Pricing Agreement according to the Income Tax Law Article 18 Paragraph 3A had been increasing, so they are more careful in doing foreign transactions. This result is also consistent with the research conducted by Rosa et al., (2017) and Nugraha (2016).

Table 4. Model Summary

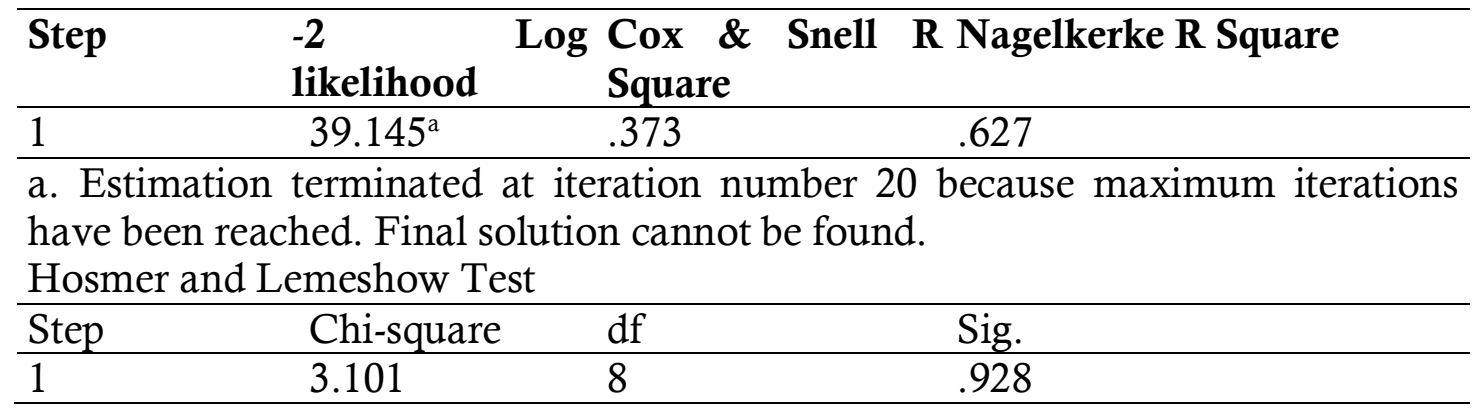

The second research model is done using Moderated Regression Analysis (MRA). The feasibility of the second research model used Hosmer and Lemeshow's Goodness of Fit Test. The initial value of $-2 \log$ Likelihood is 81.101 . However after independent variables 
and moderation variables were included, then the final value of -2 Log Likelihood decreased in value of 41.956 the final value of $-2 \log$ Likelihood becomes 39.145. This impairment of 2 Log Likelihood showed that the second regression model was better or, in other words, was the hypothesised model fit with data.

Based on the test results obtained, the value of Nagelkerke $R$ Square was 0.627, which meant that the variability of the dependent variable that could be explained by independent variables and moderation variable was $62.7 \%$; the remaining $49.9 \%$ was explained by other variables outside the research model.

Based on the calculation result of chi square in Hosmer and Lemeshow showed the value of 3.101 with significance probability of 0.928 which the value was far above 0.05 . Therefore, it could be concluded that the model used was able to predict it's observation value. And that result also showed that the regression model was proper to be used for the subsequent analysis.

Based on the second testing model used to test moderation effects for the third hypothesis $\left(\mathrm{H}_{3}\right)$ was accepted, the research result showed that good corporate governance moderated the effect of tax rate to transfer pricing with significance value of 0.006 with coefficient value of 9.841 . The testing result of fourth hypothesis $\left(\mathrm{H}_{4}\right)$ was rejected, the research result showed that good corporate governance did not moderate the effect of tunnelling incentive to transfer pricing with a significance value of 0.998 .

Good corporate governance strengthens the positive relationship of tax rate to transfer pricing. It could be explained that, the application of good corporate governance which was measured by the reputation of Big Ten Public Accountant Firms, was able to affect the company to reduce the tax burden in the scheme of transfer pricing. This was caused by the companies audited by non-Big Four Public Accountant Firms, which had a higher cheating rate in taxation activities compared with companies audited by Big Four Public Accountant Firms (Maraya \& Yendrawati, 2016). Meanwhile according to Shay (2017) it was basically very hard to identify the selling price of mining products that met the limit of reasonableness, especially sales transactions to affiliated parties in foreign countries and on the supply chain scheme done by mining business in providing services by the parent company in foreign countries to mining natural resources producing companies. This effort was generally prevalent to be done because it was an efficiency effort, business synergy and also focus in essence, not only to minimise or avoid tax in the practice. However, this research result was not consistent with the research conducted by Gandasari and Herawaty (2015) who stated that good corporate governance did not moderate company earnings management policy.

Good corporate governance was not as a moderation variable that affected tunnelling incentive to the practice of transfer pricing. It meant that the application of good corporate governance had no impact to the relationship of tunnelling incentive to transfer pricing. This research result was consistent with the research conducted by Herawaty and Anne (2017) which stated that the company's good corporate governance had no impact to foreign ownership; the percentage of foreign ownership had no impact to 
the application of good corporate governance, or there was no good corporate governance application in the decision of transfer pricing.

\section{CONCLUSION}

Based on the testing result and discussion to the research, it could be concluded that (1) Tax rate had a positive impact on the decision of transfer pricing. (2) Tunnelling incentive had no impact on the decision of transfer pricing. (3) Good corporate governance moderated the effect of tax to transfer pricing. (4) Good corporate governance did not moderate the effect of tunnelling incentive to transfer pricing.

Based on the research result and conclusion, the implications of this research are: (1) This research result to be used as the evaluation for the government in determining policies related to transfer pricing. (2) This research result could provide information to stakeholders related to the practice of transfer pricing to mining companies in Indonesia.

The limitations and shortages of this research could be improved in further researches: (1) Further research could use different company sectors with a longer time span so that the research result could be better (2) Further research could be used to measure dummy variable, so that the research result could be more accurate (3) Further research could use different moderating variables and independent variables.

\section{REFERENCES}

Gandasari, I., \& Herawaty, V. (2015). Pengaruh Karakteristik Perusahaan Terhadap Perataan Laba dengan Good Corporate Governance sebagai Variabel Moderasi (Studi Empiris pada Perusahaan Manufaktur yang Terdaftar di Bursa Efek Indonesia). Jurnal Magister Akuntansi Trisakti (e-Journal), 2(1), 73-94.

Ghazali, Imam. (2016). Aplikasi Analisis Multivariete. Semarang: Badan Penerbit Universitas Diponegoro

Hartati, Desmiyawati, Julita (2015). 2015. "Tax Minimization, Tunneling Incentive Dan Mekanisme Bonus Terhadap Keputusan Transfer Pricing Seluruh Perusahaan Yang Listing Di Bursa Efek Indonesia." Jurnal SNA 2 (2): 241-46.

Hidayat, Wahyu Wastam (2019). 2018. "Pengaruh Pajak Dan Tunneling Incentive Terhadap Keputusan Transfer Pricing Pada Perusahaan Pertambangan Yang Terdaftar Di Bursa Efek Indonesia (BEI) Periode 2012-1017." Seminar Nasional Pakar Ke 115 (1): hal. 235-240.

Jafri, Hasan Effendi, and Elia Mustikasari. 2018. "Pengaruh Perencaan Pajak, Tunnneling Incentive Dan Aset Tidak Berwujud Terhadap Perilaku Transfer Pricing Pada Perusahaan Manufaktur Yang Memiliki Hubungan Istimewa Yang Terdaftar Di Bursa Efek Indonesia Periode 2014-2016." Berkala Akuntansi Dan Keuangan Indonesia 3 (2): 63. https://doi.org/10.20473/baki.v3i2.9969.

Lo, Agnes W.Y., Raymond M.K. Wong, and Michael Firth. 2010. "Can Corporate Governance Deter Management from Manipulating Earnings? Evidence from Related-Party Sales Transactions in China." Journal of Corporate Finance 16 (2): 225- 
35. https://doi.org/10.1016/j.jcorpfin.2009.11.002.

Maraya, Amila Dyan, and Reni Yendrawati. 2016. "Pengaruh Corporate Governance Dan Corporate Social Responsibility Disclosure Terhadap Tax Avoidance: Studi Empiris Pada Perusahaan Tambang Dan CPO." Jurnal Akuntansi \& Auditing Indonesia 20 (2): 147-59. https://doi.org/10.20885/jaai.vol20.iss2.art7.

Marfuah, Syahidatul, Siti Nurlaela, and Anita Wijayanti. 2019. "Beban Pajak, Nilai Perusahaan Dan Exchange Rate Dan Transfer Pricing Pada Perusahaan Pertambangan." Jurnal Ekonomi Paradigma 21 (01): hal. 73-81. https://journal.uniba.ac.id/index.php/PRM/article/view/161/0.

Noviastika, Dwi, Yuniadi Mayowan, and Suhartini Karjo. 2016. "Pengaruh Pajak, Tunneling Incentive Dan Good Corporate Governance (GCG) Terhadap Indikasi Melakukan Transfer Pricing Pada Perusahaan Manufaktur Yang Terdaftar Di Bursa Efek Indonesia (Studi Pada Bursa Efek Indonesia Yang Berkaitan Dengan Perusahaan Asing)." Jurnal Perpajakan 8 (1): 1-9.

Novriansa, Azim. 2019. "Sektor Pertambangan Rawan Manipulasi Transfer Pricing?" DDTC News. https://news.ddtc.co.id/sektor-pertambangan-rawan-manipulasitransfer-pricing-17422?page_y=401\%0Ahttps: / / news.ddtc.co.id/sektorpertambangan-rawan-manipulasi-transfer-pricing-17422?page_y $=0$.

Putri, Vidiyanna Rizal. 2019. "Analisis Faktor Yang Mempengaruhi Transfer Pricing Pada Perusahaan Manufaktur Di Indonesia." Jurnal Manajemen Dayasaing 21 (1): 111. https://doi.org/10.23917/dayasaing.v21i1.8464.

Sari, Ayu Nurmala, and Siti Puryandani. 2019. "Pengaruh Pajak, Tunneling Incentive, Good Corporate Governance Dan Mekanisme Bonus Terhadap Transfer Pricing (Studi Kasus Pada Perusahaan Pertambangan Yang Tercatat Di BEI Periode 20142017)." Sustainable Competitive Advantage-9 (Sca-9) FEB UNSOED 9 (148): hal. 148-156. http://jp.feb.unsoed.ac.id/.

Syam, M Ardiansyah. 2017. "Peran Mediasi Opini Audit Atas Pengaruh Pengendalian Internal Berbasis Sarbanes Oxley Act Dan Keandalan Pelaporan Keuangan Terhadap Kualitas Audit ( Studi Internal Audit Pada Perusahaan Publik Di Indonesia )." Business \& Economics 1 (2).

Ulum, Roudhotul. 2017. "Kelebihan Peran Terhadap Kinerja Auditor Dengan Kecerdasan Spiritual Sebagai Variabel Pemoderasi." E-Journal Ekonomi Bisnis Dan Akuntansi 2 (2).

Yulianti, Sri, and Sistya Rachmawati. 2019. "Tax Minimization Sebagai Pemoderasi Pada Pengaruh Tunnelling Incentive Dan Debt Convenant Terhadap Ketetapan Transfer Pricing." Jurnal Akuntansi Berkelanjutan Indonesia 2 (2): 165. https://doi.org/10.32493/jabi.v2i2.y2019.p165-179.

Yuniasih, Rasmini and Wirakusuma. 2017. "Pengaruh Pajak Dan Tunneling Incentive Pada Keputusan Transfer Pricing Perusahaan Manufaktur Yang Listing Di Bursa Efek Indonesia." Manajemen \& Bisnis 7 (1): 1-23. http://library1.nida.ac.th/termpaper6/sd/2554/19755.pdf. 